necessary legislation, and some surprise has been expressed abroad at the long delay in obtaining ratification by Great Britain.

The Bill, which is about to pass into law, like that which has been passed in Norway, actually goes beyond the terms of the convention in one or two respects. Not only does it prohibit altogether the capture of what are known as 'Right' whales and of whales below certain sizes, to be prescribed for the different species, as well as of females accompanied by their young, but it also gives power to the licensing authority to establish a close season should this be deemed advisable. Furthermore, while the Geneva convention applies only to the whalebone whales, the present Bill gives authority for extending its provisions to any other species of whale, should such extension be internationally agreed upon. This clause might possibly become of great importance if, at any time, there should be a revival of the sperm whale fishery.

\section{Recent Acquisitions at the British Museum}

THe Department of Zoology has received as a donation from the Rowland Ward Trustees a crabeating opossum (Didelphys cancrivorus) and a rat-tailed opossum (Metachirus nudicaudatus). A rare treekangaroo (Dendrolagus ursinus) from New Guinea is the gift of Sir Frank Colyer. The Study Collection has been enriched through the gift from Col. J. Hamilton Leigh of a collection of fifty mammals, mostly from Scotland. The most important specimens in this collection are a series of Scottish wild cats. The Department of Entomology has received as a gift from Dr. G. Arnold, Director of the Rhodesian Museum, the very valuable collection of ants which formed the basis of his "Monograph of the Formicidæ of South Africa" published in the Annals of the South African Museum (766 pp., 9 plates, 1915-1924). The collection contains upwards of 7,000 specimens, comprising examples of 653 species many of which have hitherto been unrepresented in the Museum. In the economic life of most tropical countries ants are an important factor, principally in the control of other insects, especially the so-called white ants. In this connexion, Dr. Arnold states that the food of one large group of ants consists of 80 per cent at least of these very serious pests. The Department of Botany has purchased sixty-four bundles of plants from the Saffron Walden Museum. There are about 3,500 foreign specimens many of which were purchased by W. Gibson at A. B. Lambert's sale. The most important of these are about 150 plants collected by the Rev. E. D. Clarke on his travels in the Crimea, Greece, Troy and elsewhere. It is probable that additional historical material will be recognised, as the collection is worked through.

Fragments weighing $4 \frac{1}{2} \mathrm{lb}$. of meteoric stones which fell on April 8, 1932, near Temiki on the north-eastern border of the Gash delta (about 250 miles east of Khartoum) have been presented to the Department of Minerals by the Director of the Geological Survey of the Anglo-Egyptian
Sudan. This is the first meteorite to be recorded from the Sudan, and it appears to be of an unusual type. Pieces of two notable iron meteorites, one from the meteorite crater recently recognised near Odessa in Texas, and the other from the 15-ton mass at Mbosi in Tanganyika Territory have been presented respectively by Mr. George C. Fraser of New York and Mr. H. V. B. Lloyd-Philipps. The latter has also given a rich specimen of gold quartz from a newly discovered reef in the Lupa goldfield, Tanganyika Territory. Gold specimens from three mines in the Tati district, Bechuanaland Protectorate, and a nugget of platinum from Abyssinia, have been given by Mr. Hugh S. Gordon. Metajarlite, a new mineral from Greenland, is presented by Dr. Richard Bogvad of Copenhagen, and lusakite, a new cobalt mineral named after the new capital of Northern Rhodesia, by Mr. A. C. Skerl. A faceted gem of olivine from Burma, of a rich colour and weighing 101.75 carats, and some tektites 'rizalites', recently discovered in the Philippine Islands, and of unknown origin, have been purchased.

\section{Liver Rot and the Drought}

The Ministry of Agriculture and Fisheries points out that, as a result of the prolonged drought, the breeding places of the water-snail which is responsible for the early stages of development of the liver fluke, which causes 'liver rot' of cattle and sheep, have been considerably reduced, large areas of wet land having dried and only small wet patches and pools left. An opportunity is thus afforded for taking decisive measures for the eradication of the liver fluke from the farm. It is recommended that the remaining haunts of the snail should be dressed with a mixture of finely powdered bluestone and dry sand, in the proportion of 1 to 4 , at the rate of one-quarter to one-half hundredweight to the acre. A second dressing should be applied, if possible, after an interval of three weeks, animals being kept away from the treated ground until after rain has fallen. A further measure is to treat all adult sheep with carbon tetrachloride or with extract of male fern, which will expel any mature flukes the animals may be carrying. Further particulars are given in Leaflet No. 89, which may be obtained free of charge from the Ministry, 10 Whitehall Place, S.W.1.

\section{American Ascent into the Stratosphere}

THE ascent of an observation balloon into the stratosphere, organised by the National Geographic Society and the U.S. Army Air Corps, described in NATURE of July 28, p. 132, took place over Rapid City, North Dakota, on July 29 ; but, after rising $60,000 \mathrm{ft}$. , the balloon ripped open and dropped to earth. The pilot, Major W. E. Kepner, and the observers, Capt. A. W. Stevens and Capt. O. A. Anderson, however, were saved by means of parachutes. The gondola, with the remnants of the balloon, fell into a field near Loomis, Nebraska. According to the Times report, it was much damaged, but most of the scientific instruments escaped harm. 